\title{
ECOLOGY AND DIVERSITY OF ECTOMYCORRHIZA IN MOIST TROPICAL FOREST OF SUNSARI DISTRICT, EASTERN NEPAL
}

\author{
Sabitri Shrestha ${ }^{1,2}$, Tilak Prasad Gautam ${ }^{3 *}$, Tej Narayan Mandal ${ }^{4}$, Hari Prasad Aryal ${ }^{1}$ \\ ${ }^{l}$ Central Department of Botany, Tribhuvan University, Kirtipur, Nepal \\ ${ }^{2}$ Central Campus of Technology, Tribhuvan University, Dharan, Nepal \\ ${ }^{3}$ Department of Botany, M. M. A. M. Campus, Tribhuvan University, Biratnagar, Nepal \\ ${ }^{4}$ Department of Botany, Post Graduate Campus, Tribhuvan University, Biratnagar, Nepal \\ "Corresponding author: tilak.gautam@mmamc.tu.edu.np, tilakg673@gmail.com
}

(Received: January 29, 2021; Revised: May 05, 2021; Re-revised: May 17, 2021; Accepted: June 04, 2021)

\begin{abstract}
An ectomycorrhiza plays a vital role in the maintenance and strengthening the forest ecosystems and diversity. This study attempts to assess the ecology and diversity of ectomycorrhiza in tropical Sal (Shorea robusta Gaertn.) forest in Sunsari district, eastern Nepal. The collection of ectomycorrhiza was carried out from June to September (rainy season) for the year 2019-2020. A total of 18 species of ectomycorrhiza belonging to 12 genera and 7 families were collected. Russulaceae was found to be the dominant family representing 7 species. As per the diversity indices, the Shannon Weiner index and Simpson's index were found to be 2.60 and 0.913 , respectively indicating a higher value for the index of diversity. The results conclude that the moist tropical forest of Sunsari district is rich in ectomycorrhizal fungi, which consequently may provide a great opportunity for nutrient absorption.
\end{abstract}

Keywords: Basidiocarps, Dipterocarpaceae, Hemileccinum hortonii, Russula, Shorea robusta.

\section{INTRODUCTION}

Ectomycorrhiza (ECM) is an association of fungal mycelia with roots of plants, mostly in woody trees, which formed by fungi infecting the roots of approximately $2 \%$ of vascular plants (Brundrett \& Tedersoo, 2018). Ectomycorrhiza forms a hyphal mantle around root tips and a hartig net of hyphae penetrates between the cortical root cells. The fungi provide more nutrients and water to their host plant and obtain the photosynthates from the host plant through intense hyphae. These fungi also help in the growth of the host plant (Pyasi et al., 2013), provide resistance to stresses (Hachani et al., 2020) and diseases (Veselá et al., 2019).

Ectomycorrhiza plays an essential role in nutrient cycling in the forest ecosystems and thus helps in the proper functioning of the forest ecosystem (Liu et al., 2020). These fungi form a fruiting body called basidiocarp that protrudes from the ground. Basidiocarps are the reproductive structure of ECM. Fungal partner, ECM under the class basidiomycetes belonged to diversified families: Agaricaceae, Boletaceae, Cantherellaceae, Clavulinaceae, Cortinariaceae, Diplocystideaceae,

Entolomataceae, Hydangiaceae, Hygrophoraceae, Sclerodermataceae, Sebacinaceae, and Tricholomataceae (Disyatat et al., 2016). Plants in the family namely Acaciaceae, Betulaceae, Caesalpinaceae, Casuarinaceae, Dipterocarpaceae, Fabaceae, Gnetaceae, Juglandaceae, Myrtaceae, Nyctanginaceae, Phyllanthaceae, Pinaceae, Polygonaceae, and Salicaceae are found to be associated with the ECM (Corrales et al., 2018).
The tropical forest of Nepal is mainly dominated by Shorea robusta Gaertn. (Sal) belonging to the family Dipterocarpaceae which is distributed on the plains and lower foothills of the Himalayas including the valleys (Gautam \& Devoe, 2006), within an altitudinal range of 62 to $1500 \mathrm{~m}$ above mean sea level (msl). Sal, an important timber plant has the widest distribution range in Nepal, India, Bangladesh, Bhutan and South China (Sapkota, 2009). Research on the mushrooms of Nepal have been carried by some authors previously (Adhikari, 2014; Pokhrel, 2016). Updated data revealed about 1,291 mushroom species have been reported in Nepal (Devkota \& Aryal, 2020).

Christensen (2009) reported a total of 58 ectomycorrhizal species in the subtropical Schima-Castanopsis forest in central Nepal. Baral et al. (2015) studied the macrofungal species composition and richness of Shorea robusta forests in the mid-hill region of central Nepal and found that, among the total macrofungi, the proportion of mycorrhiza was $<40 \%$, indicating the deteriorated conditions of the forest before the conservation practice.

Forest is one of the most important natural resources of Nepal. Various ecological parameters like species composition, production and fine root dynamics have been studied in the tropical Shorea robusta forest of eastern Nepal, (Gautam \& Mandal, 2018; Bhattarai et al., 2020). Disturbance in the tropical forest of eastern Nepal caused a significant loss of biomass $(53 \%)$, net primary production (44\%), carbon sequestration capacity, and nutrient dynamics (Gautam \& Mandal, 2016). Bhattarai et al. (2020) documented important information on fine root 
dynamics in the Shorea robusta forest ecosystem which prevails an opportunity to understand the ecology and diversity of ectomycorrhiza.

ECM plays a vital role in the maintenance and strengthening the forest ecosystems and diversity (Liu et al., 2020). The species composition and diversity of macrofungi vary with the availability of nutrients, moisture, forest types, and also the magnitude of disturbance (O'Hanlon \& Harrington, 2012). Shorea robusta forests of the eastern region of Nepal are less explored in the context of mycorrhizal diversity. Information on these fungi is important as they absorb the nutrients and water from the soil for the host plant which eventually helps for better forest management. The main objective of this study was to explore the ectomycorrhizal diversity in the tropical Shorea robusta forest of the Sunsari district of eastern Nepal.

\section{MATERIALS AND METHODS}

\section{Study area}

Present study area is a moist tropical forest of Charkoshe jungle which is located in the Bhabar region of Sunsari district, Nepal. It lies between latitude $26^{\circ} 41^{\prime} 56.03^{\prime \prime} \mathrm{N}$ to $26^{\circ} 48^{\prime} 21.15^{\prime \prime} \mathrm{N}$ and longitude $87^{\circ} 09^{\prime} 34.56^{\prime \prime} \mathrm{E}$ to $87^{\circ} 21^{\prime} 14.4^{\prime \prime}$ E (Fig. 1) within an altitudinal range of 280 to $370 \mathrm{~m}$ above sea level. The total area of the Shorea robusta forest is 11394 ha (Gautam \& Mandal, 2016), it lies in the catchment of the Koshi River. The mean monthly minimum temperature ranged from $10.7^{\circ}$ to $25.3^{\circ} \mathrm{C}$ and maximum temperature ranged from $21.4^{\circ}$ to $32.8^{\circ} \mathrm{C}$ (Fig. 2). The average annual rainfall was 2055.70 $\mathrm{mm}$. Climatic data of the study area was collected from the Department of Hydrology and Meteorology, Dharan, Government of Nepal for the period of 2006 to 2020.

The forest is dominated by Shorea robusta and other main associated species are Haldina cordifolia (Roxb.), Lagerstroemia parviflora Roxb., Syzygium cumini (L.), and Cassia fistula L. The forest is also the habitat of some rare and medicinal plants, e.g. Dalbergia latifolia Roxb., Desmodium oojeinensis (Roxb.) H. Ohashi, Acacia catechu (L.) Willd, Holorrhena pubescens Wall. ex G. Don and Terminalia chebula Retz. The soil $(0-15 \mathrm{~cm}$ depth) of this region is slightly acidic with $\mathrm{pH} 5.6$ and loamy soil with organic carbon concentration of $3.07 \%$ (Gautam \& Mandal, 2013).

\section{Sample collection and identification}

Samples of basidiocarps were collected regularly in the rainy season (June to September) in the years 2019-2020. Using the quadrat method $(10 \mathrm{~m} \times 10 \mathrm{~m})$ applicable for the sampling of trees, the basidiocarps were collected from the tree rhizosphere. At each collection, basidiocarps from each quadrat were recorded. After noting the morphological characteristics of the basidiocarps like, size, shape, color, the texture of cap, the lower surface of the cap, and the base of the basidiocarps, they were kept in the paper bag.
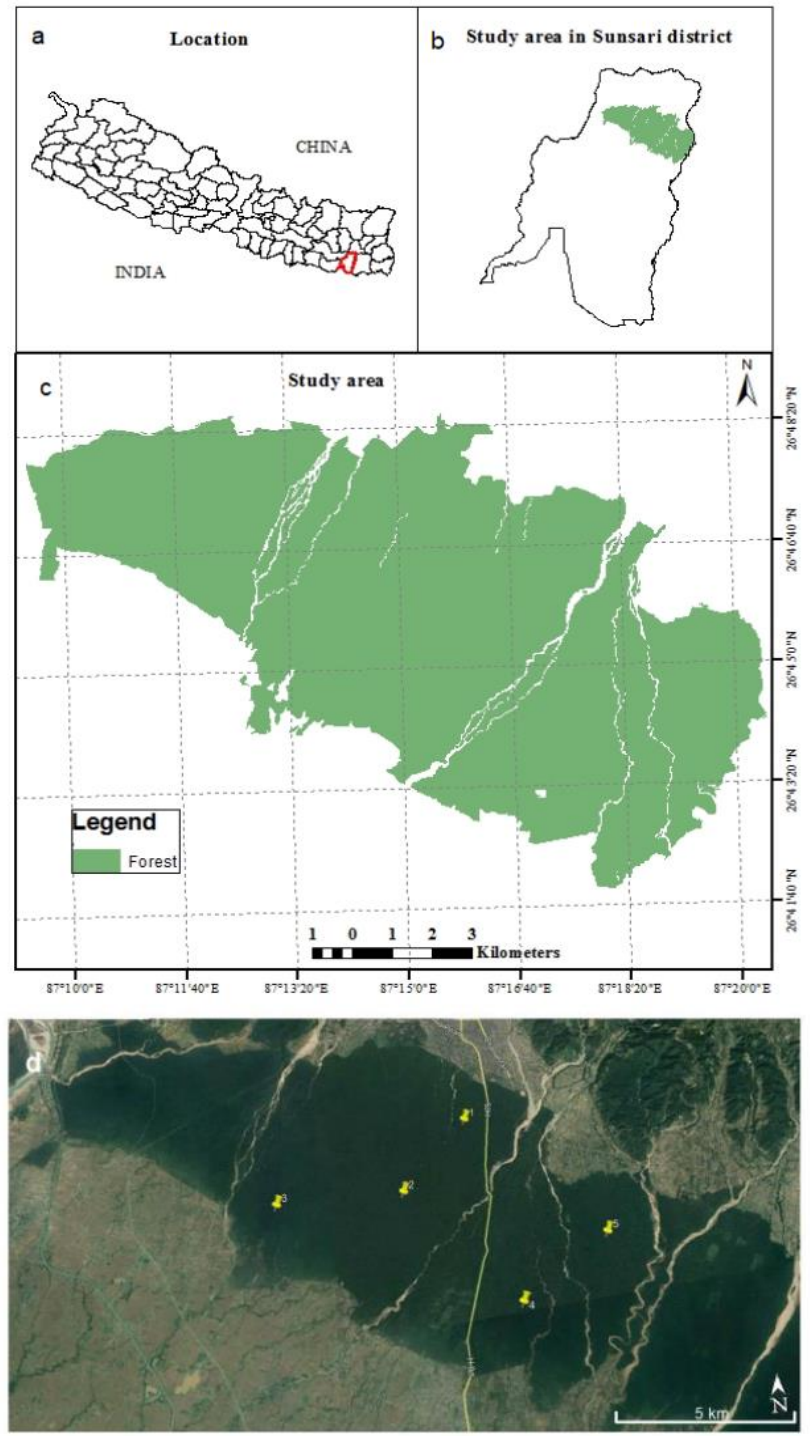

Fig. 1. (a) Map of Nepal's districts and location of Sunsari district where the site is located as marked, (b) with the location of tropical moist forest (Charkoshe forest, shaded area, (c) location of the main study sites and (d) sampling locations (Source: Geographic Information Infrastructure Division, Survey Department, Government of Nepal)

The identification was done with the help of relevant literatures (Dickinson \& Lucas, 1979; Singer, 1986; Adhikari \& Bhattarai, 2014). Basidiocarps were preserved wet as well as dry. For drying, wire trays with basidiocarps were kept over the hearth near about $40^{\circ} \mathrm{C}$. After the basidiocarps were well dried, they were packed in cellulose paper bags with some naphthalene balls. For wet preservation of basidiocarps, they were kept in a 
solution of distilled water, alcohol, and formalin in the ratio of 70:25:5 (Ainsworth, 1971). All the specimens of basidiocarps were preserved in the laboratory of the Department of Biology, Central Campus of Technology, Dharan, Nepal.

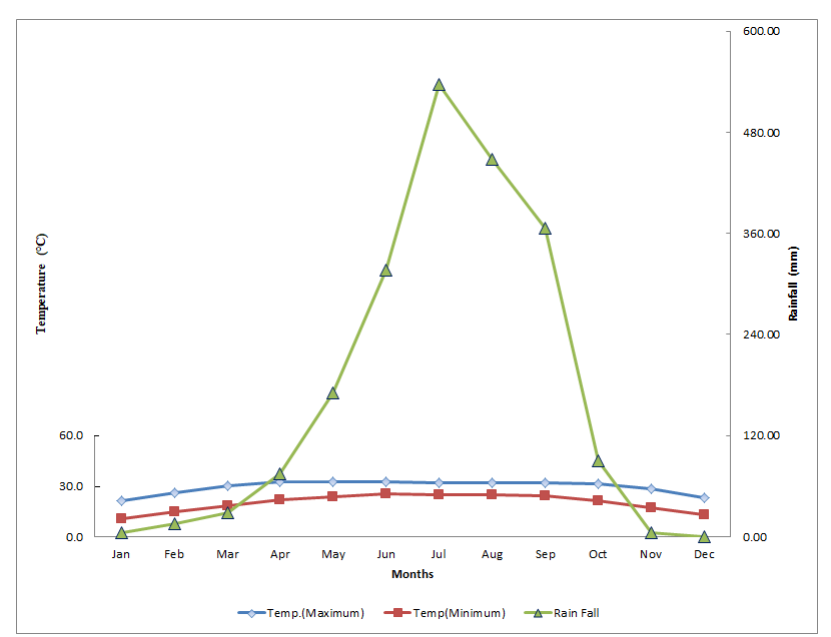

Fig. 2. Ombrothermic representation of the climate of the moist tropical forest of Sunsari district (Data pertain to the period 2006-2020; source: Department of Meteorology, Nepal)

\section{Quantitative analysis}

The formulae used in quantitative analysis to reveal the diversity of ectomycorrhiza were as follows:

Relative frequen cy $=\frac{\text { Frequency of individual } \text { specie }}{\text { Total frequency of all species }} \times 100$

Relative abundance $=\frac{\text { Abundance of individual specie }}{\text { Total abundance of all species }} \times 100(2)$

Relative density $=\frac{\text { Density of individual } \text { specie }}{\text { Total density of all species }} \times 100$

The diversity index $\left(\mathrm{H}^{\prime}\right)$ for ectomycorrhiza was calculated by using the Shannon-Wiener Index (Shannon $\&$ Weaver, 1963), as given in equation (4).

$$
\mathrm{H}^{\prime}=-\sum \mathrm{Pi} \ln \mathrm{Pi}
$$

Where, $\mathrm{Pi}$ is the proportional abundance of $\mathrm{i}^{\text {th }}$ species $=$ $(\mathrm{ni} / \mathrm{N}) ; \mathrm{ni}=$ the number of individuals in the $\mathrm{i}^{\text {th }}$ species, and $\mathrm{N}=$ the total number of individuals.

The diversity index is a mathematical representation of species diversity in a community. Shannon diversity index (Simpson, 1949), as given in equation (5), is commonly used to characterize species diversity in a community.

Simpson index of diversity $=1-\mathrm{D}$

Where, $\mathrm{D}=\sum \mathrm{n}(\mathrm{n}-1) / \mathrm{N}(\mathrm{N}-1), \quad(\mathrm{n}=$ number of individuals of each species, $\mathrm{N}=$ total number of individual of all species). Simpson's diversity index determines the chances that a species could be encountered and its value lies between 0 and 1 .

The indices of similarity (S) and dissimilarity were calculated using the formula given by Sorensen index (Sorensen, 1948), as given by equation.

$$
\mathrm{S}=2 \mathrm{C} / \mathrm{A}+\mathrm{B}
$$

Where, $\mathrm{A}=$ number of species in ecosystem, $\mathrm{B}=$ number of species in ecosystem, $\mathrm{C}=$ number of species common to both the ecosystem, and dissimilarity index $=1-\mathrm{S}$.

\section{RESULTS AND DISCUSSION}

Based on the morphological identification, the ectomycorrhiza found diversified in seven families namely: Amanitaceae, Boletaceae, Diplocystidiaceae, Hydnaceae, Hydnangiaceae, Russulaceae, and Sclerodermataceae. The family with the richest species was Russulaceae with 7 species followed by Boletaceae with 4 species, as shown in Fig 3. It was found that various species of ectomycorrhiza were associated with the different tree species growing in the Shorea robusta forest with varied basidiocarps. Most of the shapes of basidiocarps resembled the shape of an umbrella and some puffballs (Fig. 4).

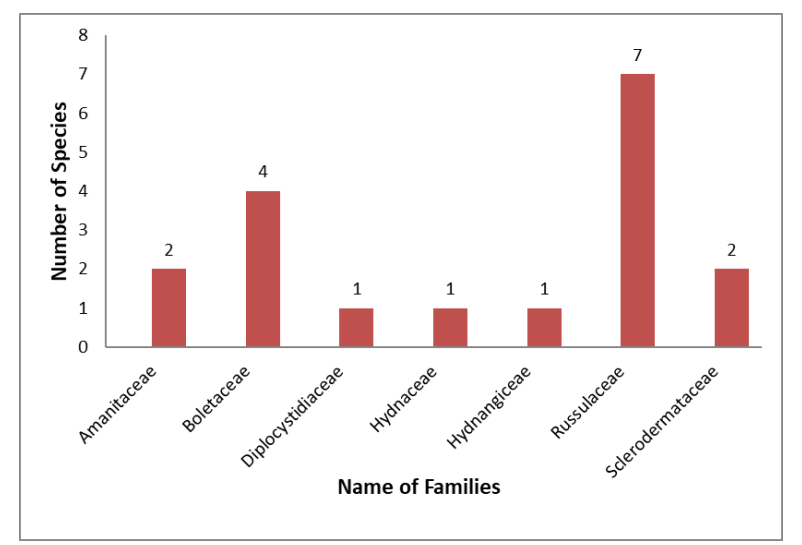

Fig. 3. Families of ectomycorrhiza representing the number of species in moist tropical Sal forest of Sunsari district

A total of 18 ectomycorrhizal species under 12 genera falling in 7 families were reported (Fig. 4, plates 1-18). Russula brevipes had the highest relative frequency of $15.71 \%$ followed by Laccaria laccata of $11.43 \%$. The highest relative abundance was scored by Cantharellus cibarius $(22.63 \%)$ and relative density scored for Laccaria laccata was $16.43 \%$ as shown in Table 1 . The analysis of ectomycorrhizal diversity in the study area revealed the Shannon-Weiner index of 2.60 and Simpson's diversity index of 0.913 . Most of the species were frequent in the rainy season while fewer basidiocarps were found at the end of September. Basidiocarps of Astraeus hygrometricus (Fig. 4, plate 3) was found during the onsets of rains. Species of Russula 
Ecology and diversity of Ectomycorrhiza in moist tropical forest of Sunsari district ...

were found frequently in the forest soil, sometimes hidden under the litter whereas Tylopilus was found in only one quadrat showing its fewer occurrence. The Russula Pers.2 with developmental stages of basidiocarps was also encountered in a single tree stand Fig. 4 (Plates 14a and $14 b)$.
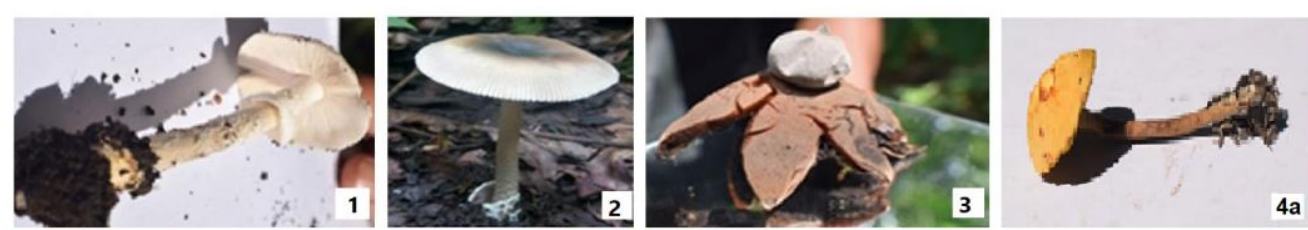

$4 a$
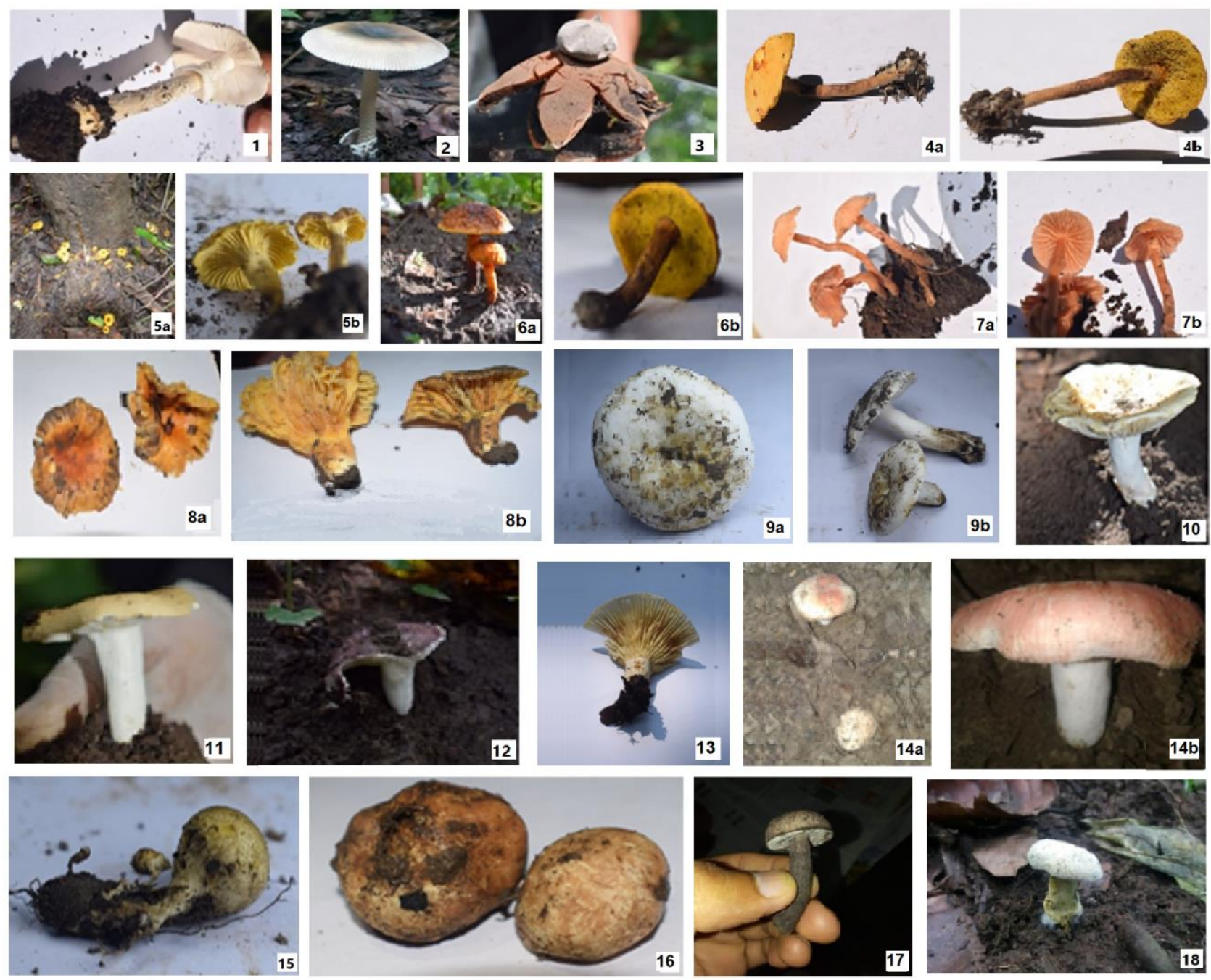

Fig. 4. Ectomycorrhiza in the moist tropical Sal forest of Sunsari district, Nepal

Different ectomycorrhizal species were found near a single host tree. This shows that a single host tree can have a symbiotic association with many types of ectomycorrhiza, and vice-versa (Mulyani et al., 2014). The present results show that most of the tree species were colonized with a member of Russulaceae which is in agreement with the results reported elsewhere (Sharma et al., 2009; Kumar \& Atri, 2019). The species Hemileccinum hortonii (Fig. 4, plate 6a and 6b) has been previously reported in Schima-Castanopsis subtropical forest, Nepal by Christensen (2009) as Boletus aff. hortinii.

The species Boletus hortonii, Leccinum hortonii, and Xerocomus hortonii are the synonyms which are recently updated to Hemileccinum hortonii by Kuo and
Ortiz (2020) based on molecular and morphological identification. The species Hemileccinum hortonii has a wrinkled orange-brown to a brown-reddish colored cap. This species has a yellow-colored hymenophore that does not change color when injured, and is its distinguishing feature. The stipe has small, rigid projections called scabers. Stipe is solid, entirely orange-yellow at first, which slowly turns dark-brownish from the base when matured. This species is located in the moist tropical forest (present study area) having an altitude of 280 to 370 $\mathrm{m}$ asl (Gautam \& Mandal, 2016) up to sub-tropical forest ranging from 700-1500 $\mathrm{m}$ asl (Christensen, 2009).

The major factors for the formation of basidiocarps are temperature, precipitation, and humidity (Hernandez \& Linera, 2011; Tapwal et al., 2013). The rich biodiversity 
of ectomycorrhiza in the present forest may be due to high rainfall during the rainy season. Increasing moisture content of the soil favors the basidiocarp development and enhances the development of luxuriant vegetation due to proper nutrient management (Mulyani et al., 2014). Thus, ectomycorrhiza forms an immense network of hyphae between trees in a forest ecosystem, sharing water, and nutrients, resulting in the development of a healthy forest ecosystem. Kennedy et al. (2007) and Kranabetter et al. (2009) reported that ECM fungi have an important role in tree regeneration and ecological function in forest ecosystems. Moreover, the ECM have a beneficial effect on the productivity of the host plant and also support the growth of the seedlings in both Dipterocarpaceae forests and mixed forest of pines and broadleaf trees (Ishida et al., 2007).

Table 1. Ectomycorrhiza in the moist tropical Sal forest of Sunsari district, Eastern Nepal. (Plate numbers correspond to those provided in Fig. 2)

\begin{tabular}{|c|c|c|c|c|c|}
\hline $\begin{array}{l}\text { Plate No. } \\
\text { in Fig. } 4\end{array}$ & Name of the species & Family & $\begin{array}{l}\text { Relative } \\
\text { frequency }\end{array}$ & $\begin{array}{l}\text { Relative } \\
\text { abundance }\end{array}$ & $\begin{array}{l}\text { Relative } \\
\text { density }\end{array}$ \\
\hline 1 & Amanita ovoidea (Bull.) Link & Amanitaceae & 4.29 & 1.80 & 1.44 \\
\hline 2 & Amanita vaginata (Bull.) Lam & Amanitaceae & 7.14 & 4.74 & 6.34 \\
\hline 3 & Astraeus hygrometricus (Pers.) Morgan & Diplocystidiaceae & 7.14 & 9.70 & 12.97 \\
\hline 4 & Boletus L. & Boletaceae & 5.71 & 4.31 & 4.61 \\
\hline 5 & Cantharellus cibarius Fr. & Hydnaceae & 2.86 & 22.63 & 12.10 \\
\hline 6 & $\begin{array}{l}\text { Hemileccinum hortonii (A.H. Sm. \& Thiers) } \\
\text { M. Kuo \& B. Ortiz }\end{array}$ & Boletaceae & 4.29 & 7.90 & 6.34 \\
\hline 7 & Laccaria laccata (Scop.) Fr. & Hydnangiaceae & 11.43 & 7.68 & 16.43 \\
\hline 8 & $\begin{array}{l}\text { Lactarius hygrophoroides } \quad \text { Berk. \& } \\
\text { M.A.Curtis }\end{array}$ & Russulaceae & 2.86 & 4.85 & 2.88 \\
\hline 9 & Lactifluus vellereus (Fr.) Kuntz & Russulaceae & 4.29 & 3.59 & 6.34 \\
\hline 10 & Russula brevipes Peck & Russulaceae & 15.71 & 2.84 & 8.36 \\
\hline 11 & Russula flavida Frost ex Peck & Russulaceae & 4.29 & 2.87 & 2.31 \\
\hline 12 & Russula xerampelina (Schaeff.) Fr. & Russulaceae & 2.86 & 1.62 & 0.86 \\
\hline 13 & Russula Pers.1. & Russulaceae & 7.14 & 4.96 & 6.63 \\
\hline 14 & Russula Pers.2. & Russulaceae & 4.29 & 3.23 & 2.59 \\
\hline 15 & Scleroderma areolatum Ehrenb & Sclerodermataceae & 4.29 & 7.90 & 6.34 \\
\hline 16 & Scleroderma cepa (Pers.) Fr. & Sclerodermataceae & 7.14 & 3.45 & 4.61 \\
\hline 17 & Strobilomyces Berk. & Boletaceae & 2.86 & 3.77 & 2.02 \\
\hline 18 & Tylopilus P. Karst. & Boletaceae & 1.43 & 2.16 & 0.58 \\
\hline
\end{tabular}

\section{Diversity of Ectomycorrhiza in Sal bearing forest}

The value of the diversity index shows that the present study area has a high species diversity of ectomycorrhiza. Estimating the diversity indices is very useful for understanding the functioning of forest ecosystems. In a mature Sal forest, Mandal (2012) reported the relationships among tree diversity indices where ShannonWeiner index was 1.66, while index of dominance (Simpson's index) was 0.30 . It showed higher equitability 0.69 as the concentration of dominance was low.

In the present study, diversity indices of ectomycorrhiza showed same trend between Shannon-Weiner and Simpson's indices, projecting a higher value of share in dominance. The trend of diversity indices suggested the existence of diversified nature of ectomycorrhiza which may help to increase the absorption capacity of nutrients and water for the host plant. The values for Shannon Weiner index (2.602) and Simpson's index (0.913) of the study area are comparable to the values of diversity indices (Shannon, 3.455 and Simpson, 0.959) of macrofungi, where nearly half of the macrofungi were ectomycorrhizal in Sal forest ecosystem of the lateritic region of West Bengal, India (Pradhan et al., 2012).

The Sorensen's similarity index estimated for the study showed higher similarity with Sal forest of lateritic region of West Bengal, India (69.56 \%) followed by Sal forest of 
Ecology and diversity of Ectomycorrhiza in moist tropical forest of Sunsari district ...

Central India (60\%), and the least similarity with Sal forest of Nadia district, India (28.57 \%) (Table 3 ).

Table 2. A comparative account of important ectomycorrhizal genera of various Sal bearing forests regarding the present study area

\begin{tabular}{|c|c|c|c|c|c|c|c|}
\hline $\begin{array}{l}\text { Ectomyco- } \\
\text { rrhizal genera }\end{array}$ & $\begin{array}{c}\text { Eastern } \\
\text { Nepal } \\
\text { (Present } \\
\text { study) } \\
\text { (Stand A) }\end{array}$ & $\begin{array}{c}\text { Madhupu, } \\
\text { Bangladesh } \\
\text { (Islam et } \\
\text { al., 2007) } \\
\text { (Stand B) }\end{array}$ & $\begin{array}{c}\text { Central } \\
\text { India } \\
\text { (Sharma et } \\
\text { al., 2009) } \\
\text { (Stand C) }\end{array}$ & $\begin{array}{c}\text { West Bengal, } \\
\text { India } \\
\text { (Pradhan et } \\
\text { al., 2012) } \\
\text { (Stand D) }\end{array}$ & $\begin{array}{c}\text { Central } \\
\text { Nepal } \\
\text { (Baral et } \\
\text { al., 2015) } \\
\text { (Stand E) }\end{array}$ & $\begin{array}{c}\text { Nadia, India } \\
\text { (Pramanik \& } \\
\text { Chaudhuri } \\
\text { 2017) } \\
\text { (Stand F) } \\
\end{array}$ & $\begin{array}{c}\text { Gajni, } \\
\text { Bangladesh } \\
\text { (Joty et al., } \\
\text { 2020) } \\
\text { (Stand G) }\end{array}$ \\
\hline Amanita & + & + & + & + & - & - & + \\
\hline Astraeus & + & - & - & + & - & + & - \\
\hline Boletus & + & - & + & - & - & - & - \\
\hline Cantharellus & + & - & + & - & + & - & - \\
\hline Coltricia & - & - & - & + & + & - & - \\
\hline Hemileccinum & + & - & - & - & - & - & - \\
\hline Hygrocybe & - & - & - & + & - & - & - \\
\hline Inocybe & - & - & - & + & - & - & - \\
\hline Laccaria & + & + & - & + & + & + & - \\
\hline Lactarius & + & + & + & + & + & - & + \\
\hline Lactifluus & + & - & - & - & - & - & - \\
\hline Leccinum & - & - & + & - & - & - & - \\
\hline Psilothus & - & - & + & - & - & - & - \\
\hline Russula & + & + & + & + & + & - & + \\
\hline Scleroderma & + & + & + & + & + & - & - \\
\hline Strobilomyces & + & & - & + & - & - & - \\
\hline Suillus & - & + & - & - & - & - & - \\
\hline Tylopilus & + & - & - & + & - & - & - \\
\hline
\end{tabular}

Table 3. Matrix of Sorensen's similarity indices for different Sal bearing forests

\begin{tabular}{|l|l|l|l|l|l|l|l|}
\hline & Stand A & Stand B & Stand C & Stand D & Stand E & Stand F & Stand G \\
\hline Stand A & 1 & & & & & & \\
Stand B & 0.555 & 1 & & & & & \\
Stand C & 0.6 & 0.571 & 1 & & & & \\
Stand D & 0.695 & 0.588 & 0.421 & 1 & & & \\
Stand E & 0.555 & 0.667 & 0.571 & 0.588 & 1 & & \\
Stand F & 0.285 & 0.25 & 0 & 0.307 & 0.25 & 1 & \\
Stand G & 0.4 & 0.667 & 0.545 & 0.428 & 0.444 & 0 & 1 \\
\hline
\end{tabular}

The dissimilarity index for the study area ranged between $30.5 \%$ (Sal forest of lateritic region of West Bengal, India) and $71.5 \%$ (Sal forest, Nadia district, India). The presence of the genera Lactarius and Russula in six different forest ecosystems out of seven forests suggested the genera being the most common in Sal bearing forest (Table 2). During the rainy season, large numbers of fruiting bodies were observed but only species of ectomycorrhiza was selected in the sampling and saprophytic fungi have been excluded. As a result, ECM was altogether 18 in number. However, in comparison to the present study, the ECM species in the Shorea robusta forest of central India (Sharma et al., 2009) and the lateritic region of West Bengal (Pradhan et al., 2012) were 61 and 28, respectively. The higher number of ECM in these forests may be due to the intensive study period of 4 years. This suggests that intensive study is required for the present study area of Nepal. Regarding the frequency of ECM, those species which are abundant inside the soil may rarely produce fruiting bodies. Besides, those species which commonly produce fruiting bodies outside may not be frequent at below ground (Dahlberg, 2001) 


\section{CONCLUSION}

The present study revealed that the Shorea robusta forest of Sunsari district, Nepal is rich in biodiversity of ectomycorrhizal fungi as suggested by the indices of biodiversity. The leading family of ECM is Russulaceae with maximum genera of Russula and Lactarius showed presence in a wide range of Shorea robusta forests of Nepal. It can be assumed that the ecosystem services like supplying nutrients, water and enhancing the growth and production of host plant is distinctly contributed by the members of Russulaceae and Boletaceae. The list of ectomycorrhiza provides the baseline information in producing a checklist of ectomycorrhiza of Shorea robusta forest in the study areas of Nepal. Subsequent research will explore more numbers of ectomycorrhizal fungi through the morphological and molecular-based study of both fruiting bodies as well as ectomycorrhizal root tips.

\section{ACKNOWLEDGMENTS}

The authors would like to acknowledge the contribution of the University Grants Commission (UGC), Nepal for providing the Ph.D. research grant to the first author. Authors are also grateful to the Central Department of Botany, Kirtipur and Central Campus of Technology, Dharan for providing the laboratory facilities.

\section{REFERENCES}

Adhikari, M. K. (2014). Mushrooms of Nepal (2 $2^{\text {nd }}$ ed.). Kathmandu, Nepal: K.S. Adhikari, p. 340.

Adhikari, M. K., \& Bhattarai, K. R. (2014). Catalog of fungi preserved in National Herbarium and Plant Laboratories (KATH), Mycology section, Godavari. Lalitpur, Nepal: Department of Plant Resources.

Ainsworth, G. C. (1971). Ainsworth and Bisby's dictionary of fungi. Surrey, England: CMI, Kew.

Baral, S., Thapa-Magar, K. B., Karki, G., Devkota, S., \& Shrestha, B. B. (2015). Macrofungal diversity in community-managed Sal (Shorea robusta) forests in central Nepal. Mycology, 6(3-4), 151-157.

Bhattarai, K. P., Mandal, T. N., \& Gautam, T. P. (2020). Effect of altitude on nutrient concentration, nutrient stock, and uptake in the fine root of Sal (Shorea robusta Gaertn.) forest in Terai and hill areas of eastern Nepal. Journal of Institute of Science and Technology, 25(1), 24-29.

Brundrett, M., \& Tedersoo, L. (2018). Evolutionary history of mycorrhizal symbiosis and global host plant diversity. New Phytologist, 220, 1108-1115.

Christensen, M. (2009). Phenology of ectomycorrizal fungi in subtropical evergreen castanopsis forest. Botanica Orientalis, 6, 8-11.
Corrales, A., Henkel, W. T., \& Smith, M. E. (2018). Ectomycorrhizal associations in the tropicsbiogeography, diversity patterns and ecosystem roles. New Phytologist, 220(4), 1076-1087.

Dahlberg, A. (2001). Community ecology of ectomycorrhizal fungi: an advancing interdisciplinary field. New Phytologist, 150, 555-562.

Devkota, S., \& Aryal, H. P. (2020). Wild Mushrooms of Nepal. In M. Siwakoti, P. K. Jha, S. Rajbhandary, \& S. K. Rai (Eds.), Plant diversity in Nepal (pp. 4154), Kathmandu: Botanical Society of Nepal.

Dickinson, C., \& Lucas, J. (1979). Encyclopedia of mushrooms. London, UK: Orchid Publication.

Disyatat, N. R., Yomyart, S., Sihanonth, P., \& Piapukiew, J. (2016). Community structure and dynamics of ectomycorrhizal fungi in a dipterocarp forest fragment and plantation in Thailand. Plant Ecology and Diversity, 9(5-6), 577-588.

Gautam, K. M., \& Devoe, N. (2006). Ecological and anthropogenic niches of sal (Shorea robusta Gaertn. f.) forest and prospects for multiple-product forest management- a review. Forestry, 79(1), 81-101.

Gautam, T. P., \& Mandal, T. N. (2013). Soil characteristics in moist tropical forest of Sunsari district, Nepal. Nepal Journal of Science and Technology, 14, 35-40.

Gautam, T. P., \& Mandal, T. N. (2016). Fine root biomass and production in tropical moist forest of eastern Nepal. International Journal of Ecology and Environmental Sciences, 42(S), 29-41.

Gautam, T. P., \& Mandal, T. N. (2018). Storage and flux of nutrients in a disturbed and undisturbed tropical moist forest of Eastern Nepal. International Journal of Forestry Research, 12 pages. https://doi.org/10.1155/2018/8516321

Hachani, C., Lamhamedi, M.S., Cameselle, C., Gouveia, S., El Abidine, A.Z., Khasa, D.P., \& Béjaoui, Z. (2020). Effects of ectomycorrhizal fungi and heavy metals $(\mathrm{Pb}, \mathrm{Zn}$, and $\mathrm{Cd})$ on growth and mineral nutrition of Pinus halepensis seedlings in North Africa. Microorganisms, 8(12), 2033. https://doi.org/10.3390/microorganisms8122033

Hernandez, M.G., \& Linera, G.W. (2011). Diversity of macromycetes determined by tree species, vegetation structure, and microenvironment in tropical cloud forest in Veracruz, Mexico. Botany, 89, 203-206.

Ishida, T. A., Nara, K., \& Hogetsu, T. (2007). Host effects on ectomycorrhizal fungal communities: insight from eight host species in mixed conifer- broadleaf forests. New Phytologist, 174, 430-440. 
Islam, K. K., Khokon, M. A. R., Pervin, M. J., Rahman, M. M., \& Vacik, H. (2007). Prevalence of ectomycorrhizal. Journal of Agroforestry and Environment, 1(1), 1-6.

Joty, A. A., Aminuzzaman, F. M., Sultana, A., Tanjina, A., Sonchita, D. R. B, \& Islam, M. N. (2020). Diversity, distribution and morphology of wild mushrooms collected from Gajni forest of Bangladesh. International Journal of Environment, 9(2), 234-255.

Kennedy, P. G., Hortal, S., Bergemann, S.E., \& Bruns, T. D. (2007). Competitive interaction among three ectomycorrhizal fungi and their relation to host plant performance. Journal of Ecology, 95, 1338-1345.

Kranabetter, J. M., Durall, D. M., \& MacKenzie, W. H. (2009). Diversity and species distribution of ectomycorrhizal fungi along productivity gradients of a southern boreal forest. Mycorrhiza, 19, 99-111.

Kumar, J., \& Atri, N. S. (2019). Characterization and identification of ectomycorrhizae of Russula (Russulaceae: Basidiomycota) associated with Shorea robusta. Journal of Tropical Forest Science, 31(1), 11-124.

Kuo, M., \& Ortiz-Santana, B. (2020). Revision of leccinoid fungi, with emphasis on North American taxa, based on the molecular and morphological data. Mycologia, 112, 197-211.

Liu, Y., Li, X., \& Kou, Y. (2020). Ectomycorrhizal fungi: Participation in nutrient turnover and community assembly pattern in forest ecosystems. Forest, 11(4), 453. https://doi.org/10.3390/f11040453

Mandal, T. N. (2012). Vegetational recovery of landslide damaged sites in the Sal (Shorea robusta) forest ecosystem of eastern Siwaliks, Nepal Himalaya. Journal of Institute of Science and Technology, 17, 151-165.

Mulyani, R. B., Sastrahidayat I. R., Abdai A. L., Djauhari, S. (2014). Exploring ectomycorrhiza in peat swamp forest of Nyaru Menteng Palangka Raya Central Borneo. Journal of Biodiversity and Environmental Science, 5(6), 133-145.

O’Hanlon, R., \& Harrington, T. J. (2012). Macrofungal diversity and ecology in four Irish forest types. Fungal Ecology, 5, 499-508.

Pokhrel, C. (2016). Cultivation of oyster mushroom: a sustainable approach of rural development in
Nepal. Journal of Institute of Science and Technology, 21(1), 56-60.

Pradhan, P., Dutta, A. K., Roy, A., Basu, S. K., \& Acharya, K. (2012). Inventory and spatial ecology of macrofungi in the Shorea robusta forest ecosystem of lateritic region of West Bengal. Biodiversity, 13, 88-99.

Pramanik, S., \& Chaudhuri, S. (2017). Macrofungal diversity in the forest litter of Nadia district, West Bengal, India. African Journal of Microbiology Research, 11(22), 927-944.

Pyasi, A., Soni, K. K., \& Verma, R. K. (2013). Effect of ectomycorrhizae on growth and establishment of Sal (Shorea robusta) seedlings in central India, Nusantara Bioscience, 5(1), 44-49.

Sapkota, I. P. (2009). Species Diversity, Regeneration and Early Growth of Sal Forest in Nepal: Responses to Inherent Disturbances Regimes (Ph. D. Thesis). Swedish University of Agriculture Sciences, Alnarp, Sweden.

Shannon, C. E., \& Weaver, W. (1963). The mathematical theory of communication. University of Illinois Press, Urbana, p. 117.

Sharma, R., Rajak, R. C., \& Pandey, A. K. (2009). Ectomycorrhizal mushrooms in Indian tropical forests. Biodiversity, 10(1), 25-30.

Simpson, E. H. (1949). Measurement of diversity. Nature, 163, 688. http://dx.doi.org/10.1038/163688a0

Singer, R. (1986). The agaricales in modern taxonomy ( $4^{\text {th }}$ ed.). Dehradun, India, p. 981.

Sorensen, T. A. (1948). A method of establishing groups of equal amplitude in plant sociology based on similarity of species content, and its application to analyses of the vegetation on Danish commons. Kongelige Danske Videnskabernes Selskab, Biologiske Skrifter, 5, 1-34.

Tapwal, A., Kumar, R., \& Pandey, S. (2013). Diversity and frequency of macrofungi associated with wet evergreen tropical forest in Assam, India. Biodiversitas, 14(2), 73-78.

Veselá, P. Vasutova. M., Hofmannová, K., EdwardsJonášová, M., \& Cudlín, P. (2019). Ectomycorrhizal community on Norway spruce seedlings following bark beetle infestation. Forests, 10(9), 740. https://doi.org/10.3390/f10090740 